\title{
Task-based Teaching Approach and English Writing Teaching
}

\author{
Zhipeng Liu* \\ School of foreign languages \\ Taishan University \\ Taian, Shandong, China
}

\begin{abstract}
English Writing is difficult not only for students to learn, but also for teachers to accomplish the teaching task. The English proficiency of Chinese college students is generally not high. In order to improve students' English writing level, teachers should actively change the teaching concept, give full play to students' subjective initiative in the teaching process, and apply the task-based teaching approach. After the application of this teaching approach, Students improve their language skills in specific classroom practice, develop their actual writing skills, and improve their overall quality.
\end{abstract}

Keywords-task-based teaching approach; English writing teaching; application

\section{INTRODUCTION}

Nowadays, information technology is becoming more and more popular, and the high-quality talents with English communication ability are in the urgent need. So English writing has become a crucial teaching content in the foreign language syllabus. However, in many years of English teaching, we have paid too much attention to the cultivation of listening, speaking and reading ability, but neglecting the cultivation of writing ability. In the face of the current new demands of language learners, teachers should spare no efforts to cultivate students' practical writing skills.

\section{THEORETICAL FRAMEWORK}

In recent years, a large number of researchers have called for the development of language teaching to task-based teaching (Prebhu, 1987 [2]; Nunan, 1989 [3]; Long and Crookes, 1991 [4]). The study of task-based language teaching began in the United States in the 1980s, emphasizing students' role from passive learning to active learning, making students the true master of English classroom teaching. Nunan (1989) believes that communicative tasks focus on classroom activities involving learners' understanding and communication. Students' attention is mainly focused on the meaning of language rather than the form of language [3]. Long (1989) [5] argues that a task is a paid or unpaid work done for yourself or for others, a purposeful activity that people engage in in their daily lives. Skehan (1996) thinks that the task is an activity. In this activity, the meaning is the main one. Therefore, in the

Supported by 2015 Teaching Reform Research Project of Taishan University - "Practical Research of English Vocabulary Learning for College Students of Sports and Arts Majors Based on Learning Strategy Instruction" (Grant Number 201520); The 10th Batch Teaching Reform Research Project of Taishan University - "The college English teachers' discourse studies in the process of class observation and assessing based on critical discourse analysis theory" (Grant Number 201723) communicative environment, through the rational design and control of the task, and the language is continuously obtained in the process of completing the task.[6]

\section{A. Application of task-based teaching approach in the college English writing class}

Task-based teaching is the process of cultivating students' comprehensive language ability and strengthening the practical application of language to fully reflect the communicative nature of language. Students are the dominant role in the taskdriven activities and the real masters in the process of teaching in the classroom. This means that learning is the responsibility of the students themselves. Students need to set their own goals and means to try their best to achieve the task. Students achieve the goal of learning the language while completing various tasks. At the same time, they learn to set up purposes, establish and maintain certain interpersonal relationships, form and develop their own learning motivations, and determine their own learning patterns and means. In task-based teaching, teachers get rid of the traditional classroom teaching methods, and their positioning is multi-directional. They are both planners, instructors, facilitators, monitors and helpers. Specifically, in the task-based teaching activities, under the premise of establishing the goals of each classroom teaching and the needs of students, the teacher adheres to the principle of forming a task chain which is encouraged to create a relaxed learning environment, and to promote students to learn. Then the teachers create a relaxed learning environment to promote students to learn. Task-based teaching mainly divides the classroom into three phases: pre-task, mid-task and post-task. The pre-task is mainly to design some "warm-up" activities that stimulate students' interest in learning. According to different writing purposes, different learning objects and different content themes, the teachers organize different writing preparation activities for learners. The mid tasks include writing, reporting and evaluation, with the goal of mainly designing multiple small tasks and forming a task chain. The tasks in the learning unit are designed for the students to complete in individual and group form, and then they present their tasks in the form of reports, discussions and debates. As a Result, in this stage writing is the first link, and the two parts of the report and evaluation must be flexibly arranged according to the actual needs of the teaching; the post-task is the individual or group activity according to the content of the classroom task. The form completes the writing task. The teachers and students jointly evaluate and analyze the process, 
status and results of the task execution. The teacher gives timely and effective feedback. The teacher can explain and summarize the students' writing, and encourage and praise the students' shining points.

\section{B. Several problems need to be paid attention to when using task-based teaching approach in college English writing class}

Task-based teaching puts higher demands on teachers. It requires teachers to create a better learning atmosphere for learners through new teaching concepts, complete knowledge structure, and reflective teaching methods through valuable classroom task design. Teachers must possess good classroom organization skills. However, because sometimes the teachers' poor ability, the following problems should be paid attention to in the actual classroom teaching process.

1) It is necessary to take the students' English learning practice into the consideration and flexibly arrange tasks in the teaching practice

Many teachers mistakenly interpret task-based teaching process as a process in which we only focus on the selfcentered student, ignoring some necessary tasks such as knowledge transfer, language training, and task responsibilities for students to carry out task-based teaching. The teachers hastily accepted the "task" of writing, which made it difficult for students to speak or have nothing to say from the beginning. Under the influence of exam-oriented education, Chinese college students still do not have strong independence of study, and they also need guidance and instructions from teachers. Therefore, teachers should fully consider the actual situation of the students and set realistic situations close to the students so that they can improve their writing skills in purposeful learning.

2) Avoid task-based teaching activities in the form, pay attention to scientific division of labor and management

In the task-based teaching process, group activities are the main way of improving the students' ability in the learning. However, in the actual teaching process, some teachers' group activities only stay on the surface level, being lack of scientific management and necessary division of labor. Teachers should divide the students into different groups according to their writing levels, to ensure that each student can actively participate in the activities.

3) Avoid stylizing the implementation process of the task link and enhance its flexibility

In task-based teaching about English writing, many teachers often appear to be simple and mechanically step-bystep in order to pursue the integrity of the task, lacking targeted and flexible errors. Task-based writing teaching is studentcentered, and it pays attention to the interaction and coordination of students, which helps to improve the overall quality of students, but at the same time does not completely negate the role of writing knowledge and model. The writing process, writing time, and writing process are constantly changing and adjusting according to the nature of the writing task. Therefore, its classroom mode is not unique and has diverse characteristics. Teachers should fully understand this and enrich the diverse teaching. Forms mobilize the enthusiasm of students.

\section{ReseARCH PROCESS}

\section{A. Research objects}

The focus of this study is to explore whether the task-based teaching approach can effectively improve students' writing level in the process of college English writing teaching. The research object is two classes with equivalent English writing level. The two classes are tested by different teaching methods and the data obtained before and after the experiment are quantitatively analyzed and processed by statistical software SPSS, so as to test the validity of this approach in the writing teaching process. The student writing level test scores before and after the test are important data needed in this study. The subjects were all students of Information Science and Technology of Taishan College in 2015. There were two classes, 40 students in each class, and a total of 80 people participated in the experiment. From the results of the final exams in English, the 80 English scores were all moderate, and the average scores of the two classes were not much different (the average score of a group of 40 people was 73.2 points, and the second class was 74.6 points).

\section{B. Experimental procedure}

Although Willis did not give the specific steps of the taskbased teaching approach in English writing teaching, we can divide the writing teaching process into three stages according to her three-stage theory: prewriting, writing and modification.

1) Pre-writing stage: Teachers must first prepare essay topics and collect materials related to the topic of the essay as input materials, such as videos, advertisements, recordings, news, etc., in order to stimulate students' desire to write, and to explore the deeper meaning of the topic.

2) Writing stage: First, the individual student will complete the given writing task independently within the prescribed time period, carry out the actual writing creation, and then discuss the composition in the group.

3) Modification stage: The team members report to the class in an oral form about the results of their completed learning tasks. In this process, the teacher acts as the moderator, ensuring the orderly progress of the task process, and give feedback based on the student's reporting situation. In the feedback process, teachers should first analyze their reports, and propose evaluation criteria for the topic of the article. Then teachers evaluate the student's composition according to these criteria, and then exchange the first draft between the groups. Finally, the teacher will supplement and explain the common problems of the students.

\section{Comparison of results after the test}

After a month-long trial, all the students took part in the CET 4 essay simulation test. The essay topic used this time was the December 2017 College English CET-4 essay "How to best handle the relationship between teachers and students" The title and the test essay topic before the test are essays that are closely related to the student's study life. The test scores are still given by the top three senior teachers. The average score is still used. The scoring rules used were scored and an independent sample $\mathrm{T}$ test was performed on each score. 


\section{Analysis and conclusion}

Comparing the data analyzed before and after the test, it can be seen that through one month of intensive training, the average scores of the two classes and the scores of each factor are higher than before the test. Relatively speaking, the writing performance of the first class is much higher than that of the previous class. At the beginning, due to the misunderstanding of the teaching philosophy of the task-based teaching approach, the progress of the class was slow, the writing level did not improve much, and the students were more confused. After the two task-based teaching approach was implemented, the students were able to adapt to this. The average score of the two classes was extended to 5.59 points, and the $\mathrm{P}$ value was 0.03 , which proved that there was a significant difference in the average scores of the two classes $(\mathrm{P}<0.05)$.

\section{CONCLUSION}

The improvement of students' writing skills will strengthen and consolidate other language skills. In addition to the students' own efforts, writing skills also require the careful teaching of teachers. The application of task-based teaching in the college writing class encourages the participation of students. It is effective to cultivate and improve students' writing ability and skills by completing a series of progressive task activities in writing. With the use of task-based concepts in writing teaching not only improves students' language skills, but also enables students to learn to live together, learn to do things, learn to develop, and use them through cooperative activities in task-based teaching process. The sustainable development has laid a solid foundation and improved their overall quality. This should be a consensus that our university teachers must reach.

\section{REFERENCE}

[1] Cheng Jingying. Analysis of English Writing Teaching [J]. Foreign Language Teaching and Research, 1994(2): 12-181.

[2] Prebhu. Second Language Pedagogy[M].Oxford :Oxford University Press ,1987.

[3] Nunan. Designing Tasks for the Communicative Classroom [M].Cambridge: Cambridge University Press,1989.

[4] Long and Crookes. Task-based Syllabus Design [J].TESOL Quarterly, 1991,26/1:27-551.

[5] Long. Task Group, and Task-Group Interaction[J].University of Hawaii Working Papers in English as a Second Language,1989(8):1-261.

[6] Skehan. A Framework for the Implementation of Task based Instruction [J].Applied Linguistics,1996, 17/1:39 -591.

[7] Liao Xiaoqing. The Theoretical Basis and Classroom Practice of Taskbased Teaching [J]. Foreign Language Teaching in Primary and Secondary Schools, 2014(11):1-151.

[8] Yu Guangan. Task-based teaching [J]. Foreign Language Teaching in Primary and Secondary Schools, 2002 (6): 5-91.

[9] New edition of College English. Shanghai: Shanghai Foreign Language Education Press, 2016 